\title{
Preface of the "Symposium on turbulent flows: Modeling and solution algorithms"
}

Mine Çağlar

Citation: AIP Conference Proceedings 1558, 317 (2013); doi: 10.1063/1.4825486

View online: http://dx.doi.org/10.1063/1.4825486

View Table of Contents: http://aip.scitation.org/toc/apc/1558/1

Published by the American Institute of Physics 


\title{
Preface of the "Symposium on Turbulent Flows: Modeling and Solution Algorithms"
}

\author{
Mine Çağlar \\ Department of Mathematics, Koc University, Istanbul, Turkey
}

This symposium concerns with the fundamental and applied aspects of turbulence theory. In particular, turbulent flows in the ocean, turbulent reactive flow, solution methods, subgrid modeling in Large Eddy Simulation, and random velocity fields and statistical aspects are considered.

\section{Mine Çă̆lar}

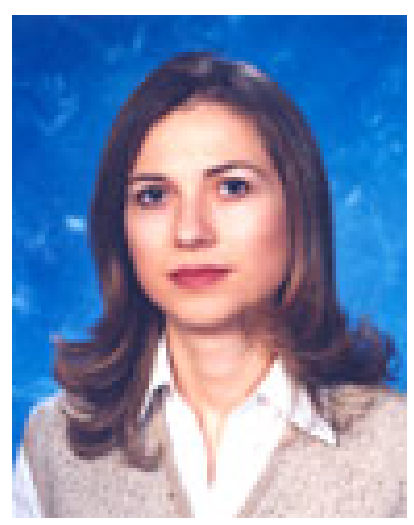

Address: Koç University

URL: http://home.ku.edu.tr/ mcaglar

Education

- $\quad$ Princeton University Ph.D. June, 1997 Statistics \& Operations Research Princeton, NJ

- $\quad$ Bilkent University M.Sc. Mar., 1991 Industrial Engineering Ankara, Turkey

- $\quad$ Middle East Tech. Univ. B.Sc. May, 1989 Industrial Engineering

\section{Research interests} Ankara, Turkey

Probability theory and stochastic processes; in particular, Markov processes, fractional Brownian motion, Levy processes, and constructions with Poisson random

\section{Experience}

- Associate Professor, Koç University, College of Sciences, 2006-Present

- Assistant Professor, Koç University, College of Sciences, 1999-2006

- Research Scientist, Bellcore, Network Design \& Traffic Research Group, 1997-1998 